\title{
Conflict management in tertiary institutions: A study of selected universities in south-western Nigeria
}

\begin{tabular}{|c|c|}
\hline $\begin{array}{l}\text { Authors: } \\
\text { Kehinde O. Os } \\
\text { Samuel O. ljim } \\
\text { Taiwo O. Ades } \\
\text { Ann D. Ojo }\end{array}$ & $\begin{array}{l}\text { akede }^{1} \\
\text { lakinwa } \\
\text { anya }^{3}\end{array}$ \\
\hline $\begin{array}{l}\text { Affiliations: } \\
{ }^{1} \text { West African } \\
\text { Company Limi } \\
\text { Nigeria }\end{array}$ & $\begin{array}{l}\text { Seasoning } \\
\text { ted, Apapa, }\end{array}$ \\
\hline $\begin{array}{l}{ }^{2} \text { Department } \\
\text { Science and P } \\
\text { Administratior } \\
\text { Ajasin Univers } \\
\text { Akoko, Nigeria }\end{array}$ & $\begin{array}{l}\text { ff Political } \\
\text { ublic } \\
\text {, Adekunle } \\
\text { ity Akungba- }\end{array}$ \\
\hline $\begin{array}{l}{ }^{3} \text { Department } \\
\text { Administration } \\
\text { Management } \\
\text { State Universi }\end{array}$ & $\begin{array}{l}\text { f Public } \\
\text {, Faculty of } \\
\text { Science, Lagos } \\
\text { ty, Nigeria }\end{array}$ \\
\hline $\begin{array}{l}\text { Correspondin } \\
\text { Kehinde Osak } \\
\text { kosakede@yal }\end{array}$ & $\begin{array}{l}\text { g author: } \\
\text { de, } \\
\text { hoo.com }\end{array}$ \\
\hline $\begin{array}{l}\text { Dates: } \\
\text { Received: } 15 \mathrm{~S} \\
\text { Accepted: } 01 \\
\text { Published: } 05\end{array}$ & $\begin{array}{l}\text { ept. } 2017 \\
\text { Dept. } 2018 \\
\text { Dec. } 2018\end{array}$ \\
\hline $\begin{array}{l}\text { How to cite th } \\
\text { Osakede, K.O. } \\
\text { S.O., Adesany } \\
\text { A.D., 2018, 'CC } \\
\text { management } \\
\text { institutions: A } \\
\text { selected unive } \\
\text { south-western } \\
\text { Africa's Public } \\
\text { Delivery and P } \\
\text { Review 6(1), a } \\
\text { doi.org/10.41 } \\
\text { v6i1.197 }\end{array}$ & $\begin{array}{l}\text { is article: } \\
\text { ljimakinwa, } \\
\text {, T.O. \& Ojo, } \\
\text { onflict } \\
\text { in tertiary } \\
\text { study of } \\
\text { rsities in } \\
\text { Nigeria', } \\
\text { Service } \\
\text { erformance } \\
\text { 197. https:// } \\
\text { O2/apsdpr. }\end{array}$ \\
\hline $\begin{array}{l}\text { Copyright: } \\
\text { (c 2018. The } A \\
\text { Licensee: AOS } \\
\text { is licensed unc } \\
\text { Creative Comr } \\
\text { Attribution Lic }\end{array}$ & $\begin{array}{l}\text { uthors. } \\
\text { IS. This work } \\
\text { der the } \\
\text { nons } \\
\text { ense. }\end{array}$ \\
\hline Read online: & \\
\hline 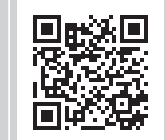 & $\begin{array}{l}\text { Scan this QR } \\
\text { code with your } \\
\text { smart phone or } \\
\text { mobile device } \\
\text { to read online. }\end{array}$ \\
\hline
\end{tabular}

Background: Conflict constitutes a major significant factor in human interaction because of the interdependent relationship of individuals. However, its effective management and strategies are imperative for growth and development in an organisation or a society.

Aim: This study examines conflict management in Nigerian tertiary institutions to examine the extent to which conflict management engendered stakeholder participation in the two institutions since their establishment and to investigate whether the performance of a conflict management board in two institutions has improved since their establishment.

Setting: Nigerian tertiary institutions - with specific reference to Lagos State University, Ojo Lagos (LASU) and Adekunle Ajasin University Akungba-Akoko, Ondo state (AAUA).

Methods: The study used primary and secondary sources, such as structured questionnaires, interviews and published journals, textbooks, newspapers, magazines and Internet. The sample size consisted of 500 respondents (280 from LASU and 220 from AAUA, respectively). Percentage method and Chi-square non-parametric technique were used to analyse the data.

Results: The study findings revealed that conflict management has engendered stakeholder participation in decision-making and conflict resolution in the selected universities. Also, the performance of the conflict management board in LASU and AAUA has recorded significant progress in terms of managing crisis and peace building.

Conclusion: The study concludes that conflict in the spate of tertiary institutions and it hinders the development of the educational system. Hence, it is impossible to attain a conducive environment in the higher institutions characterised by conflict. The study advocates for strong effective mechanisms on conflict management that will pave the way for stakeholders' participation in decision-making of institutions.

\section{Introduction}

The increase in human existence, multicultural aspects and interaction in the 21st century threaten the peace of humanity. Higher institutions in Africa, especially in Nigeria, had been litigating from academic advancement as a result of ever-increasing conflict that constitutes a significant factor in the organisation and society (Olajide 2011). Conflict, as is often said, is an integral part of human existence and an inevitable friction in any organisational structure as the stakeholders have different incompatible goals (Ibukun 1997). However, whenever a conflict occurs, it must be managed and handled constructively; else it will threaten the very existence of the organisation, and the nation and society at large.

Higher institutions in developing countries like Nigeria (e.g. universities, polytechnics, colleges of education and organisations having different mono-technic goals) are often regarded as complex institutions to manage in terms of conflict as conflict is inescapable (Bloisi 2007). Higher institutions worldwide experience different levels of conflict, but a well-managed conflict will not escalate to violence. However, conflict can cause deep rifts in the framework of an institution and it can also be a veritable tool to promote the institution to a new level of effectiveness (Fatile \& Adejuwon 2011). This implies that internally the tertiary institutions in Nigeria are shaped by various forces. These include external and internal forces within the institutional frameworks that constitute constraint to administration efficiencies. Thus, conflict is inevitable (Gbadamosi 2006). Therefore, it will be difficult for higher institutions to attain academic efficiency in an environment that engulfs crisis as witnessed in tertiary institutions in Nigeria today. The stakeholders, that is, students and staff (academic, non-academic and administrator), pose conflict which may result in protests, revolts, unrests and violence, leading to closure of academic programmes for months (Adeyemi, Ekundayo \& Alonge 2010). 
The fundamental issues in the effective management of conflicts in any society lie in giving room to individual and group participation, which is paramount to organisational development. Conflict, as is often said, is an integral part of human existence and inevitable in any organisation (Sanda 1992) as the stakeholders have different incompatible goals. However, whenever a conflict occurs, it must be managed and handled constructively; else it will threaten the very existence of the organisation, and the nation and society at large (Olaleye \& Arogundade 2013).

It has been observed that Nigerian tertiary institutions are being confronted with various constraints, such as poor infrastructures, increase in tuition fee, extortion money from students by the lecturer and sexual harassment, among others. These have given rise to distrust and hostility among the stakeholders of higher institutions, hence militating against the smooth, effective and efficient administration in the institutions (Rahimi 2002).

Educational administrators seemed not to have been proactive to the threat posed by conflict in higher institutions, which might engender the progress and development of the institutions if not properly managed. One such instance is the recent crisis that disrupted academic programmes of Lagos State University (LASU) in 2015, where the union prevented the vice chancellor Prof. John Obafunwa and some key officials in entering the main campus to performs their duties, singing and shouting 'Obafunwa must go'. Also similar incidents occurred in Adekunle Ajasin University AkungbaAkoko (AAUA), Ondo State, Obafemi Awolowo University (OAU) and University of Benni (UNIBEN), to name a few, where students set some of the school properties ablaze and destroyed properties worth millions, resulting in closing down the academic programmes for months.

Based on this context, the article focuses on the following research questions:

- To what extent has conflict management engendered stakeholder participation in LASU and AAUA?

- Has the performance of the conflict management board in LASU and AAUA improved since the establishment of the board?

This study has the following research objectives:

- to examine the extent to which conflict management engendered stakeholder participation in LASU and AAUA since their establishment

- to investigate whether the performance of the conflict management board in LASU and AAUA has improved since their establishment.

\section{Conceptual and theoretical framework}

Some scholars have claimed that conflict is perceived as negative, dysfunctional and destructive (Geoffrey 1997; Olaleye \& Arogundade 2013; Posigha \& Oghuvwu 2009), while others are of the opinion that conflict serves as a catalyst for innovation, creativity of production and efficiency (Akorede 2005; Bercovitch 2011; Fatile \& Adejuwon 2011). Thus, the definition appears curious as numerous writers believed that conflict implies negative implications to everyone concerned. However, the definitions given by Bercovitch, Fatile \& Adejuwon and Akorede show that conflict enhances positive results. Nonetheless, Olaleye \& Arogundade (2013) are of the view that conflict may be dysfunctional if not well-managed.

Other scholars such as Oladele (2011) and Adesina (2010), opine that conflict engenders interaction of persons or a group of people in relation to different expectations, interests and backgrounds in society. Going by the claim made by Oladele and Adesina above, conflict can be viewed as unavoidable and a normal part of a society or an organisation.

Ositoye et al. (2012) avert that conflict can be disagreement that exists between one or two parties. According to them, it creates situations where both parties perceived a situation in different directions in reaching compromise on issues of common interest. Thus, it may lead to protest, strikes and disruption of work activities.

From the examination of various definitions, this article likes to define conflict as a misunderstanding that arises when one or two people have different views or pursue different goals in an organisation. It is what usually occurs between students and staff (management), who are the university stakeholders.

Conflict management entails the establishment of various mechanisms to eliminate the misconception or negative feeling aspects of conflict to enhance learning and group outcomes so as to pave the way for people to achieve their goals (Adeniji 2009; Albert 2010; Goldman 1996).

Oni (2007) averted that conflict management enhances capacity through a number of measures by working with the parties involved in conflict. The above definition covers the entire area of handling conflicts positively, being proactive at and preventing conflict. In the view of Adaeze (2014), it is a diagnostic process or dialogue where strategies and intervention are designed to curtail the conflict. This implies that when conflict arises, the need is to become a positive solution provider, rather than generating a negative one, which threatens the individual or group, so as to cover conflict limitation, containment and litigation.

From the examination of various definitions, this article likes to define conflict management as measures put in place in managing conflict towards constructive action in resolving organisational conflict. This indicates that when conflict arises, the need for proper management is imperative so as to enhance positive results. 


\section{Theoretical framework}

The study anchored on the structural-functional theory of Persons (1960). This theory views that human beings normally adjust to a given structure in society. However, any adjustment in the system might lead to conflict. It means that people are irresistible to change in organisation and without proper management it may lead to destabilise the organisational objective. Some scholars such as Zahid \& Sumaira (2014) posit that it will be impossible to see a conflictless society or organisation contrary to the makeshift belief of some authors that a classless society or organisation will end conflicts all over the world. The point however remains that conflict is inevitable because it is innate in a person (Miner 1973). Thomas Hobbes captures this view eloquently when in his major work Leviathan, he described the hopeless chaos of the state of nature as a life without gentility or beauty, without charm or peace and without industry and culture (Goldman 1996). According to Alabi (2002), conflict should be managed by minimising structural changes in order to maintain stability with both the individuals and the institutions. The implication is that tertiary institutions should be proactive to organisational structures and in policymaking without taking into consideration the benefits of the stakeholders (Agbonna 2009).

\section{Conflict in the Nigerian tertiary institutions}

Conflicts in Nigerian universities are like growing monsters (Adeyemi \& Ademola 2012). Prevailing crises that Nigerian universities are currently confronting are more than what they were in the past. Conflict has remained an instrument employed by students or groups in the pursuit of their personal or collective goals and the forums put in place by the management are much more far-reaching than ever before. However, the consequence of globalisation and dynamic changes in the management of organisations have contributed positively and negatively to the Nigerian university system (Adeyemi et al. 2010); therefore, it is required to curb crisis which has become more rampant in the Nigerian tertiary institutions resulting in poor academic performance of students and poor learning environment. In brief, conflicts in Nigerian universities vary from one institution to another in terms of capacity, environment, population, goal, specialisation, governance and unionisation, among others (Ogbona, Yusuf \& Onifade 2013). It has been observed that the causes of conflicts in one university might differ from another (Ndum \& Stella 2013). However, university-based conflicts are also linked to other factors.

The challenge underlying the university system can be classified as internal and external forces which create the type and nature of conflicts in place (Okotoni 2002). Universities experience countless conflict situations, and the absence of their proper solution contributes to a highly adversary poor academic outcome.

Obasan (2004) is of the view that conflicts are unique to the university settings; it may occur based on a wide range of issues such as norms, sexual harassment, policies and student behaviour, among others, which might lead to dispute in the campus. Yet, when conflicts occur, there are many similarities in the dispute culture across universities (Idowu 2014). For instance, situations that may seemingly have no relationship with the university may become a source of major conflict and get played out at the university, which might lead to actions taken opposed by students (Adejuwon \& Okewale 2009).

\section{Research method}

The study adopted a survey research design. The reason for selecting this method was that it enables the researcher to elicit data from the respondents without any attempt to manipulate the variables. The study also employed qualitative and quantitative methods; furthermore, purposive sampling was adopted. Firstly, the study reviewed the literature on conflict management in Nigerian tertiary instructions. Data were drawn from both primary sources, which included structured interviews and questionnaires, and secondary sources, which included published journals, articles, textbooks, Internet and libraries, among others.

The study was restricted to two universities in southwestern Nigeria (LASU, Ojo Lagos and AAUA, Ondo State), and the sample size restricted to 400 university level students in the Faculty of Management and Social Sciences. The choice of the two universities was instructive. Firstly, there is evidence that these two universities had a recent crisis between the staff, students and university management and a conflict management board was established. Secondly, time and funding did not allow the researchers to expand the study to other tertiary institutions in Nigeria and Africa at large.

The total population comprised the academic and nonacademic staff, students and the university management (see Table 1).

\section{Presentation and analysis of data}

The method of data analysis and interpretation was used on a sample percentage. Sample percentage entails using the diverse responses or answers from respondents in order to categorise them and thereby draw the representative percentage for each of the groups. In testing the appropriate

TABLE 1: Total population and sample size of the respondents.

\begin{tabular}{llcc}
\hline University & Subjects & Population & Sample size (20\%) \\
\hline LASU & Academic & 100 & 20 \\
& Non-academic & 300 & 60 \\
& Management & 10 & 2 \\
& Students & 990 & 198 \\
Total & - & 1400 & 280 \\
AAUA & Academic & 75 & 15 \\
& Non-academic & 215 & 43 \\
& Management & 10 & 2 \\
& Students & 800 & 160 \\
Total & - & 1100 & 220 \\
\hline Total population & - & $\mathbf{2 5 0 0}$ & $\mathbf{5 0 0}$
\end{tabular}

LASU, Lagos State University; AAUA, Adekunle Ajasin University Akungba-Akoko. 
decision by using chi-square at 5\% level of significance, the formula for chi-square non-parametric technique is given in Equation 1:

$=X_{c}^{2}=\left(\frac{Q-\Sigma^{2}}{\Sigma}\right)$

where:

- $X^{2}=$ Chi-square calculated

- $\Sigma=$ Summation notation

- $Q=$ Observed frequency

- $d f=$ Degree of freedom will be calculated as $(r-1)(-1)$, where:

- $r=$ row

- $C=$ columns.

\section{Presentations of findings, analysis and decisions Presentation of primary data}

Table 2 shows that $96 \%$ of the sampled population returned the completed questionnaire.

\section{Results}

Question 1: In response to this question, the results showed that $400(83 \%)$ respondents said 'yes' while 80 (17\%) replied 'no'. This implies that the introduction of conflict management board engendered stakeholder participation in the two universities (LASU and AAUA).

Questions 2: Regarding this question, 470 (98\%) respondents stated 'yes' while $10(2 \%)$ said 'no'. This demonstrates how communication gap in the two universities results in conflict among the university stakeholders, thereby resulting in prolonging the academic programmes.

Question 3: In response to this question, 300 (63\%) respondents stated 'yes' while $180(37 \%)$ replied 'no'. Based

\begin{tabular}{lcc} 
TABLE 2: Questionnaire responses. & $\begin{array}{c}\text { Copies of } \\
\text { Category }\end{array}$ & $\begin{array}{c}\text { Copies of questionnaire } \\
\text { retrieved (valid) }\end{array}$ \\
\hline LASU Management & 2 & 2 \\
Academics & 20 & 19 \\
Non-academics & 60 & 58 \\
Students & 198 & 190 \\
AAUA Management & 2 & 2 \\
Academics & 15 & 15 \\
Non-academics & 43 & 40 \\
Students & 160 & 154 \\
\hline Total & $\mathbf{5 0 0}$ & $\mathbf{4 8 0}$
\end{tabular}

LASU, Lagos State University; AAUA, Adekunle Ajasin University Akungba-Akoko. on the percentage method, the performance of the conflict management board has engendered effective mechanisms such as dialogue, mediation and participation in the two universities.

Question 4: In response to this question, 345 (72\%) respondents stated 'yes' while 135 (28\%) replied 'no'. Based on the above analysis, it can be said that the two universities' (LASU and AAUA) conflict management boards are proactive to crisis (please see Table 3).

\section{Research question 1}

To what extent has conflict management engendered stakeholder participation in LASU and AAUA?

Table 4 illustrates the respondent opinion, to calculate expected value in question 1 and 2; 400 (83\%) respondents stated 'yes', while $80(17 \%)$ respondent replied No. Question 2, 470(96\%) respondents stated 'yes', 10(2\%) respondents replied 'no'.

Expected frequency for 'yes' is given in Equation 2:

$E=\frac{870 \times 480}{960}=45, E=\frac{\mathrm{TC} \times \mathrm{TR}}{\mathrm{TG}}, E=\frac{90 \times 480}{960}=45 \quad$ [Eqn 2]

where:

- $\mathrm{TR}=$ total rows

- $\mathrm{TC}=$ total columns

- $\mathrm{TG}=$ total grand

- $\mathrm{O}=$ observed frequency

- $\mathrm{E}=$ expected frequency

TABLE 4: Observed and expected value question 1 and 2.

\begin{tabular}{lccccc}
\hline Questions & 'Yes' observed & Expected & 'No' observed & Expected & Total \\
\hline Q1 & 400 & 435 & 80 & 45 & 480 \\
Q2 & 470 & 435 & 10 & 45 & 480 \\
\hline Total & $\mathbf{8 7 0}$ & - & 90 & 90 & 960
\end{tabular}

TABLE 5: Computation of Chi-square table.

\begin{tabular}{lcccc}
\hline $\mathbf{O}$ & $\boldsymbol{\Sigma}$ & $\mathbf{O}-\boldsymbol{\Sigma}$ & $(\mathbf{O}-\Sigma)^{2}$ & $\left(\frac{\mathbf{O}-\Sigma}{\Sigma}\right)^{2}$ \\
\hline $400 \dagger$ & & & 2.82 \\
$80 \dagger$ & $435 \dagger$ & -35 & 1225 & 27.22 \\
$470 \dagger$ & $45 \dagger$ & 35 & 1225 & 2.82 \\
$10 \dagger$ & $435 \dagger$ & 35 & 1225 & 27.22 \\
\hline Total & $45 \dagger$ & -35 & 1225 & $\mathbf{6 0 . 0 8}$ \\
\hline
\end{tabular}

$\dagger$, represents observed and expected values.

$d f$, degree of freedom.

TABLE 3: Percentage of questionnaire respondents.

\begin{tabular}{|c|c|c|c|c|c|}
\hline Number & Questions & 'Yes' response & Yes (\%) & ‘No' response & No $(\%)$ \\
\hline 1. & $\begin{array}{l}\text { Does conflict management enhance stakeholders' participations since its establishment } \\
\text { in your institutions? }\end{array}$ & 400 & 83 & 80 & 17 \\
\hline 2. & $\begin{array}{l}\text { Does poor communication breed conflict and disrupt academic calendar in your } \\
\text { university? }\end{array}$ & 470 & 98 & 10 & 2 \\
\hline 3. & $\begin{array}{l}\text { The performance of conflict management board engenders effective mechanisms } \\
\text { such as dialogue, mediation, participation and avoidance strategy in the university }\end{array}$ & 300 & 63 & 180 & 37 \\
\hline 4. & $\begin{array}{l}\text { Was your university conflict management board effective in the university crisis } \\
\text { resolution? }\end{array}$ & 345 & 72 & 135 & 28 \\
\hline
\end{tabular}


See Table 5 and Equation 3 for calculation of Chi-square value:

$$
X_{c}^{2}=\Sigma\left(\frac{\mathrm{O}-\Sigma}{\Sigma}\right)^{2}
$$

where:

- $X_{c}^{2}=60.08$

- $\quad d f=(R-1)(\mathrm{c}-1)$, where:

- $r=$ row

- $C=$ columns.

- $d f=(2-1)(2-1)=1 \times 1 d f=1$

- $d f=1$ at 0.05 level of significance $=3.84$

- Therefore, $X_{t}^{2}$, that is, Chi-square tabulated, is $=3.84$.

- When $X_{c}^{2}>X_{t}^{2}$ :

- accept $\mathrm{H}_{1}$ (alternative hypothesis), reject $\mathrm{H}_{0}$ (null hypothesis) $X_{c}^{2}<X_{t}^{2}$,

- accept $\mathrm{H}_{0^{\prime}}$ reject $\mathrm{H}_{1}$ because $X_{c}^{2}=60.08$ and $X_{t}^{2}=3.84$.

Decision rule: We accept $\mathrm{H}_{1}$ (60.08) and reject $\mathrm{H}_{0}$ (3.84). This indicates that conflict management has engendered stakeholder participation in LASU and AAUA.

\section{Research question 2}

Has the performance of conflict management board in LASU and AAUA improved since the establishment of the board?

Table 6 illustrates the respondent opinion, to calculate expected value in question 3 and 4; 300 (63\%) respondents stated 'yes', while 180 (37\%) respondent replied 'no'. Question 2, 354 (72\%) respondents stated 'yes', 135 (28\%) respondents replied 'no'.

See Table 7 and Equation 4 for calculation of Chi-Square value: $X_{c}^{2}=\sum\left(\frac{Q-\Sigma}{\Sigma}\right)^{2}=27$

where:

$$
\begin{aligned}
& \text { - } d f=(R-1)(\mathrm{c}-1), \text { where: } \\
& \text { - } \quad r=\text { row } \\
& \text { - } \quad C=\text { columns. }
\end{aligned}
$$

TABLE 6: Observed and expected value question 3 and 4.

\begin{tabular}{lccccc}
\hline Questions & 'Yes' observed & Expected & 'No' observed & Expected & Total \\
\hline Q3 & 470 & 407.5 & 10 & 322.5 & 480 \\
Q4 & 345 & 407.5 & 135 & 322.5 & 480 \\
\hline Total & $\mathbf{8 1 5}$ & - & 145 & - & 960 \\
\hline
\end{tabular}

TABLE 7: Computation of Chi-square table.

\begin{tabular}{lcccc}
\hline $\mathbf{O}$ & $\Sigma$ & $\mathbf{O}-\Sigma$ & $(\mathbf{O}-\Sigma)^{2}$ & $\left(\frac{\mathbf{O}-\Sigma}{\Sigma}\right)^{2}$ \\
\hline $470 \dagger$ & & & & 9.6 \\
$10 \dagger$ & $407.5 \dagger$ & 62.5 & 3906.25 & 53.9 \\
$345 \dagger$ & $72.5 \dagger$ & -62.5 & 396.25 & 9.6 \\
$135 \dagger$ & $407.5 \dagger$ & -62.5 & 396.25 & 9.6 \\
\hline Total & $72.5 \dagger$ & 62.5 & 396.25 & $\mathbf{1 2 7}$ \\
\hline
\end{tabular}

$\dagger$, represents observed and expected values

$d f$, degree of freedom
- $d f=(2-1)(2-1)=1 \times 1 d f=1$

- $d f=1$ at 0.05 level of significance $=3.84$

- Therefore, $\mathrm{X}_{\mathrm{t}}^{2}$, that is, Chi-square tabulated, is 3.84.

- When $X_{c}^{2}>X_{t}^{2}$ :

- accept $\mathrm{H}_{1}$ (alternative hypothesis), reject $\mathrm{H}_{0}$ (null hypothesis), $X_{c}^{2}<X_{t}^{2}$,

- accept $\mathrm{H}_{0^{\prime}}$ reject $\mathrm{H}_{1}$ because $X_{c}^{2}=127$ and $X_{t}^{2}=3.84$.

Decision rule: We accept $\mathrm{H}_{1}$ (127) and reject $\mathrm{H}_{0}$ (3.84). This implies the performance of conflict management board in LASU and AAUA has improved since the establishment of the board.

\section{Discussions of findings}

The importance of this research work has been to determine the extent to which conflict management enhances effective academic programmes in Nigerian tertiary institutions, thus leading to research question 1: To what extent has conflict management engendered stakeholder participation in LASU and AAUA? This question sought to find out how conflict management strategy adopted by the two selected universities paves the way for effective resolution of crisis in the university. The findings from the research revealed that conflict management has engendered stakeholder participation in decision-making in these two universities. This is in agreement with the findings of Fatile and Adejuwon (2011), who pointed out that tertiary institutions' conflict management in the two universities (LASU and AAUA) enhances a constructive communication process that paves the way for negotiators and to be guided from disrupting the university strategies towards attempting its manifestation and latent goals for conflicting parties that are systematic in the way they communicate their grievances.

Research question 2: Has the performance of conflict management board in LASU and AAUA improved since the establishment of the board? The research sought to investigate the effectiveness of the conflict management board in the management of conflict in the two universities. The research revealed that the performance of a conflict management board in LASU and AAUA has improved significantly in terms of peace building and consultation since the establishment of the board. This implies that the conflict management board in the two institutions established strategies that create avenues for discussions and dialogue for managing conflicts. This is in line with the findings of Alabi (2002), Fatile and Adejuwon (2011), and Olaleye and Arogundade (2013), who posited that managing conflict in Nigerian tertiary institutions demands democratic or participative leadership style of effective administration.

\section{Conclusion}

It has been observed that conflicts are inevitable in human life and so are they in higher institutions. Based on the findings of the study, it can be said that conflicts in the spate of tertiary institutions and they hinder the development of the educational system. Hence, it is impossible to attain 
a conducive environment in the higher institutions characterised by conflict. The fact however remains that dysfunctional consequence of conflict should be avoided, while functional conflict should be accepted.

\section{Recommendations}

Based on the findings of the study, it is recommended that tertiary institutions in Africa including Nigeria should be more democratic, dialogue oriented and consultative in decision-making so as to enhance stakeholder participation in conflict resolution. It is also recommended that tertiary institutions should adopt effective conflict management strategies that would empower the tertiary institutions in conflict consultation.

Also universities should establish rules and regulations that should be made available to all the stakeholders (students, academics and management) to avoid communication gaps and conflict within the university system.

Finally, the conflict management board should involve well-experienced and trained people in the area of human management.

\section{Acknowledgements}

We are indebted to almighty God for his endless love and divine guidance and offer our gratitude to the following persons under whom we were taught in our various institutions of learning: Profs. Adele L. Jinadu, Femi Ajayi, Ayandeji Aina, Aina Joseph, Adebajo Kunle, Jacob Fatile and Nchukwekwe Friday, Drs Igbokwe-Ibeto C.J., and Ngozi Nwogwugwu and a host of others.

This research was solely funded by the author (Dr K.O. Osakede).

\section{Competing interests}

The authors discovered that gradual reduction in the Nigeria academic standard might be attributed to prevalent crisis (conflict) in our Nation University. This propelled the authors to examine conflict management in Nigeria tertiary institutions with reference to LASU and AAUA.

\section{Authors' contributions}

O. K.O., was the project leader, S.O.I. O.T.A and D.A.O. were responsible for experimental and project design. O.K.O. performed most of the experiment. S.O.I made conceptual contributions. S.O.I., O.T.A and D.A.O. performed some of the experiments. O.K.O., S.O.I., and O.T.A prepared the samples, and calculations were performed by O.K.O, S.O.I. and O.T.A. Also, the title and problem identification of the study was structured by S.O.I. All authors agreed on it after restructuring of the topic. O.K.O and S.O.I wrote the introduction, conceptual and theoretical framework and methodology. Administration of questionnaire was done by S.O.I, O.T.A. and D.A.O. It was reviewed by the leader O.K.O. Materials were supplied by the author and co-authors while data collation and analysis were performed by S.O.I., T.O.A and A.O. Discussion of findings and way forward were performed by O.K.O.

\section{References}

Adaeze, U., 2014, 'Information dissemination for conflict management in Nigeria Tertiary Institution: Issues and prospects', Journal of Social Science 7(3), 73-77.

Adejuwon, K.D. \& Okewale, R.A., 2009, 'Ethnic militancy, insurrections and democracy in Africa: The case of Nigeria', Journal of Social and Policylssues 6(4), 123-143.

Adeniji, A., 2009, Perspectives in educational management, Ekegant Publishing Company Ltd., Lagos.

Adesina, A.D.O., 2010, Peace dilemma in Nigeria. A case of peace education programme for elementary school, Obafemi Awolowo University, Lle-Lfe, Nigeria.

Adeyemi, T.O. \& Ademila, S.O., 2012, 'Conflict management strategies and administrative effectiveness in Nigeria universities', Journal of Emerging Trend in Education Research and Policy Study 3(3), 386-375.

Adeyemi, T.O., Ekundayo, H.T. \& Alonge, H.O., 2010, 'Managing students' crisis in Tertiary Institutions in Nigeria: The way forward', Journal of Research in National Development 8(1), 20-38.

Agbonna, S.A., 2009, 'Prevalence of subculture of violence and delinquent tendencies among secondary school students in llorin, Kwarastate, Nigeria', African Journal of Historical Sciences in Education 5(1\&2), 12-32.

Akorede, Y.O., 2005, 'Women and intra gender conflicts in the African Narratives', unpublished PhD thesis, University of Ibadan, Ibadan.

Alabi, A.T., 2002, 'Conflicts in Nigeria universities: Causes and management', Journal of Public Policy and Management Studies 2(3), 110-121.

Albert, I.O., 2010, Building peace, advancing democracy, experience with the third party interventions in Nigeria's conflicts, John Archers, Ibadan.

Bercovitch, J., 2011, 'Conflict and conflict management in organisations: A framework for analysis', Journal of Social and Humanity 2(4), 65-84.

Bloisi, W., 2007, An introduction to human resources management, McGraw-Hill, London.

Fatile, J.O. \& Adejuwon, K.D., 2011, 'Conflict and conflict management in tertiary institutions: The case of Nigeria universities', European Journal of Humanities and Social Sciences 7(1), 273-288.

Gbadamosi, O., 2006, 'School and classroom management', in K. Ajayi, J. Oni \& O. Gbadamosi (eds.), Fundamentals of educational management, pp 17-96, Gbemi Sodipo Press, Abeokuta.

Geoffrey, C., 1997, 'Conflicts within the university community', Journal of Studies in Higher Education 2(1), 3-8.

Goldman, O.A., 1996, 'Conflict management in the Nigerian Baptist convention', unpublished Ph.D. thesis, University of Ibadan.

Ibukun, W.O., 1997, Educational management theory and practice, Bamgboye and Co.

Idowu, J., 2014, 'Inter-security agencies conflict at Nigeria boarders: A challenge to Nigeria national security', International Journal of Humanities and Social Science 4(7), 211-217.

Miner, J.B., 1973, The management process theory, research and practice, Macmillan, New York.

Ndum, V.E. \& Stella, M.O., 2013, 'Conflict management in the Nigerian university system', Journal of Education and Social Research 3(8), 17-23. https://doi.org/ 10.5901/jesr.2013.v3n8p17

Obasan, K.A., 2004, 'Organisational conflicts', in S.K. Balogun \& K.A. Obasan (eds.), Understanding organisational behaviour: Asocio-psychological perspective, pp. 34-58, Centre for Sandwich Programme (CESAP), Ogun.

Ogbona, A.A., Yusuf, M. \& Onifdade, A.O., 2013, 'Management information system and decision-making in Nigeria universities', An unpublished doctoral thesis, University of Ilorin.

Okotoni, C.A., 2002, Management conflict in secondary school, Obafemi Awolowo University Press, lle-Ife.

Oladele, A.A., 2011, Management conflict in secondary school, Obafemi Awolowo University Press, Ile-Ife.

Olajide, O., 2011, 'Towards the resolution of conflict for research and sustainable development in the developing countries: The role of libraries and information centres', International Journal of Library and Information Science 3(9), 195198.

Olaleye, F. \& Arogundade, B., 2013, 'Conflicts management strategies of University administrators in South-West Nigeria', Arabian Journal of Business \& Management Review 2(6), 96-104.

Oni, S.S., 2007, 'Conflict management in Nigerian Tertiary institutions: A case for corporate effectiveness', International Journal of Labour and Organizational Psychology 1(2), 74-81. 
Ositoye, W., Adebayo, A., Alade, O. \& Omolade, M., 2012, 'Dimensions of conflict and conflict management', in N. Adeyemi \& A.C. Njoku (eds.), Emerging issues in organisational management (thinking beyond the 21st century), pp. 110-1236, Allahu-Sati Printing Works, Abeokuta.

Persons, A. 1960 in Alade, O.A., 1988, 'Conflict management within the Nigerian Baptist convention 1984-1994', unpublished Ph.D. thesis, University of lbadan.
Posigha, B.A. \& Oghuvwu, F.O. 2009, Educational management: Asystem approach, Lantern Books, Haryana, India.

Rahimi, M.A., 2002, 'Towards a theory of managing organizational conflict', The International Journal of Conflict Management 3(4), 120-139.

Sanda, O.A., 1992, Managing Nigerian universities, Spectrum, Ibadan.

Zahidat, M.O. \& Sumaira, T., 2014, 'Managing conflicts in university: A group dynamic approach', llorin Journal of Education 5(2), 36-46. 